\title{
Oldest record of brittle deformation along the Median Tectonic Line: fission-track age for pseudotachylyte in the Taki area, Mie Prefecture
}

\author{
Hideo Takagi*, Koji Shimada**, \\ Hideki Iwano ${ }^{* * *}$ and \\ Tohru Danhara*** \\ Received September 8, 2009 \\ Accepted September 14, 2009 \\ * Faculty of Education and integrated Arts and \\ Sciences, Waseda University, Shinjuku-ku, \\ Tokyo 169-8050, Japan \\ ** Japan Atomic Energy Agency, FBR Monju, Tsu- \\ ruga, Fukui 919-1279, Japan \\ *** Kyoto Fission-Track Co. Ltd., Kita-ku, Kyoto \\ 603-8832, Japan \\ Corresponding author; H. Takagi, \\ hideo@waseda.jp
}

\begin{abstract}
Fission-track (FT) dating of pseudotachylyte (PST) associated with the Median Tectonic Line (MTL) in the Taki area, Mie Prefecture, SW Japan, provides new constraints on the timing of movement upon this fault. A PST vein with a thickness of about $5 \mathrm{~cm}$ yields a zircon FT age of $60.0 \pm 3.5 \mathrm{Ma}(1 \sigma)$. In contrast, a weighted average of zircon FT ages obtained for protolith samples (cataclastic mylonitized Hatai Tonalite) collected $10 \mathrm{~cm}$ and $15 \mathrm{~m}$ from the PST vein boundary is $69.8 \pm 1.2 \mathrm{Ma}$, which is significantly older than the age of the PST. Decomposition of feldspars in the PST suggests that the temperature exceeded $1100{ }^{\circ} \mathrm{C}$, which is sufficient to completely erase previous fission tracks in zircon within several seconds. The distribution of fission-track lengths in zircon from the PST vein also supports the interpretation that the zircon FT age was completely reset during frictional fusion of the PST vein. Considering an apatite FT age of 38.0 \pm 1.5 Ma for the host rock, the age of the PST indicates that the frictional fusion was occurred during cooling of the Ryoke granite at temperatures between $250{ }^{\circ} \mathrm{C}$ (closure temperature of the zircon FT system) and $100{ }^{\circ} \mathrm{C}$ (closure temperature of the apatite FT system). This PST age is comparable with the oldest K-Ar age obtained for fine fractions of MTL fault gouge derived from both the Sanbagawa pelitic schist and the Izumi Group in Shikoku, indicating that the initiation of brittle fault movement associated with formation of the PST and/or fault gouges along the MTL had occurred by $60 \mathrm{Ma}$.
\end{abstract}

Keywords: fission-track dating, pseudotachylyte, Median Tectonic Line, Ryoke granite

\section{Introduction}

Pseudotachylyte (PST) is a product of frictional melting along a fault surface, and the dating of pseudotachylyte along a major fault is therefore significant to extract major events in the history of brittle fault activity. The applicability of the fission-track (FT) dating of PST has been recently clarified by annealing experiments (Murakami et al., 2006b). They revealed that only about 4 seconds could erase all fission tracks in zircon grains at about $900{ }^{\circ} \mathrm{C}$ from annealing experiment. Murakami and Tagami (2004) determined FT ages firstly on the PST from the Nojima Fault. The FT dating has been also applied to the PST from the Asuke Shear Zone, SW Japan (Murakami et al., 2006a) and landslide-generated PST from Langtang, Nepal (Takagi et al., 2007).

PST veins are commonly thin (less than $1 \mathrm{~cm}$ ) and pulverization is commonly associated with frictional melting. These features commonly make it difficult to identify and separate a sufficient number of zircon gains for FT dating. Thick PST vein has been found along the Median Tectonic Line (MTL) from the Taki area, Mie Prefecture (Shimada et al., 2001). The PST exhibits typical melting-quench textures with decompositions of feldspar suggesting that the melting temperature was greater than $1100{ }^{\circ} \mathrm{C}$ (Shimada et al., 2001; Spray, 1992), which is sufficiently high that fission tracks are completely annealed within very short time scales that are geologically instantaneous (Murakami et al., 2006b)

In this contribution we first report the FT ages for the PST along the MTL in comparison with those for the protoliths about $10 \mathrm{~cm}$ and $15 \mathrm{~m}$ apart from the PST vein border, and secondly discuss their significance for the history of brittle deformations along the MTL.

\section{Geologic outline}

The host rocks of the PST described here are mylonites derived from the Hatai Tonalite, the oldest Ryoke granitic rocks in the eastern Kinki region, which consists of plagioclase, quartz, hornblende, biotite (mostly chloritized), and minor amounts of K-feldspar with accessories of allanite, apatite, zircon, and titanite. The Hatai Tonalite yields K-Ar ages of 72.9-84.3 Ma (hornblende) and 63.0-70.1 Ma (biotite). It also yields FT zircon ages 


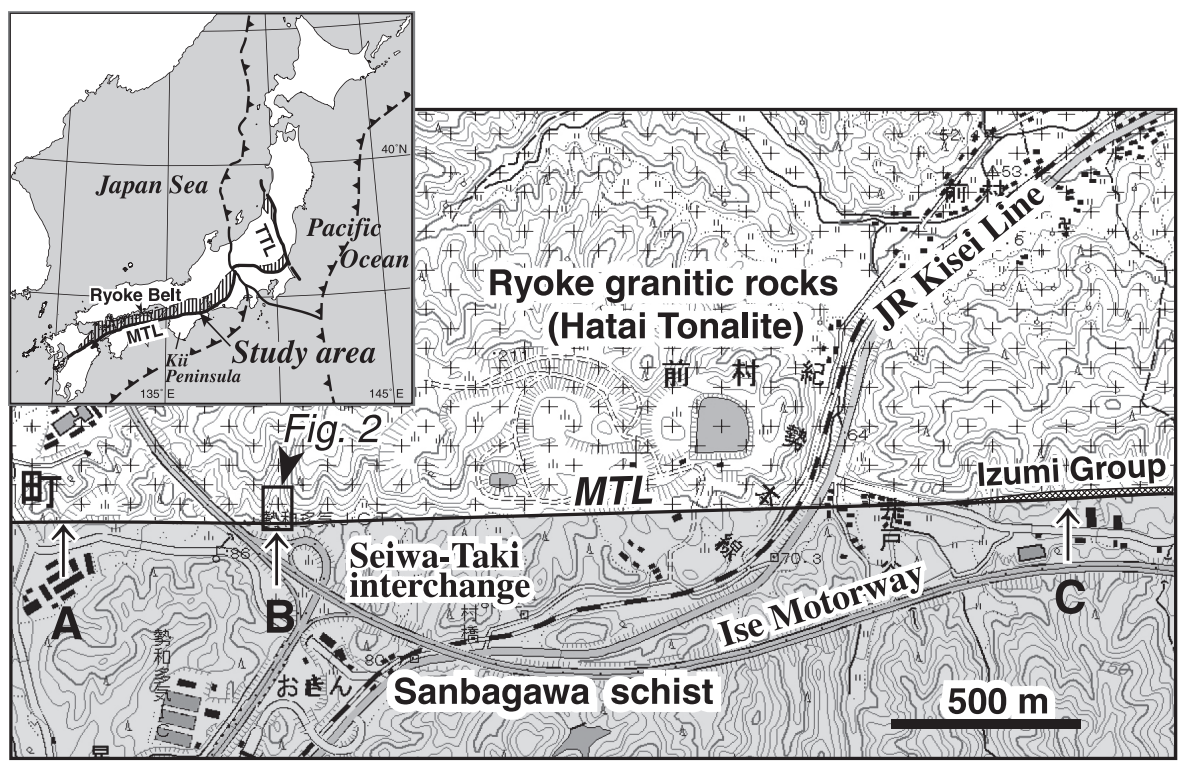

Fig. 1. Index map and the location of outcrops (A, B and C) of the MTL in the Taki area, Mie Prefecture, southwest Japan. Pseudotachylyte occurs at area B close to the Seiwa-Taki interchange (junction). Topographic map is a part of the 1: 25,000 Kuzukayama sheet map of the Geographical Survey Institute. of 52.4-59.5 Ma (Takagi et al., 1989) and 56.4-63.8 Ma (Tagami et al., 1988), and FT apatite ages of 43.7-59.9 Ma for the samples apart $(>7 \mathrm{~km})$ from the MTL and of 28.5-30.0 Ma near $(<7 \mathrm{~km})$ the MTL (Tagami et al., 1988). The Hatai Tonalite underwent mylonitization in a zone extending about $1 \mathrm{~km}$ from the MTL under amphibolite to greenschist facies conditions (Sakakibara, 1995; Shimada et al., 1998). The mylonitization is post-dated by cataclasis at shallower depths forming a cataclastic fault zone (200-300 m thick) immediately to the north of the MTL (e.g., Takagi, 1985). The deformation sequence is considered to have occurred under a transpressional regime at an oblique convergent margin during the Late Cretaceous to early Paleogene (Shimada et al., 1998)

The outcrop of the PST described in this paper is located about $100 \mathrm{~m}$ north of the MTL, close to the Seiwa-Taki interchange of the Ise Motorway (Loc. B in Fig. 1). The PST occurs sporadically over $30 \mathrm{~m}$ on a southwest-facing exposure (Fig. 2). The MTL strikes E-W and dips about $70^{\circ}$ to the north (Fig. 2). To the south of the MTL, the Sanbagawa pelitic schist underwent cataclasis to form a fault gouge (about $1 \mathrm{~m}$ thick) and sheared schist characterized by the presence of lenticular quartz veins adjacent to the MTL. To the north of the MTL, mylonitic structures are overprinted by a phase of cataclasis associated with the formation of the PST, and accompanying mineral veining and alteration. Although it is difficult to recognize the PST veins at the outcrop because of their greyish blue-green color similar to that of the surrounding fault rocks, observation of polished slices clearly reveals characteristic structures for PST such as fault and injection veins (Takagi et al., 2001). Attitudes of the PST fault veins are similar to those of the E-W striking mylonitic foliation and the MTL. Along the MTL, intensively altered and weathered reddish-brown cataclastic rocks occur in a zone with a width of up to $40 \mathrm{~m}$, but the mylonitized tonalite around the PST vein

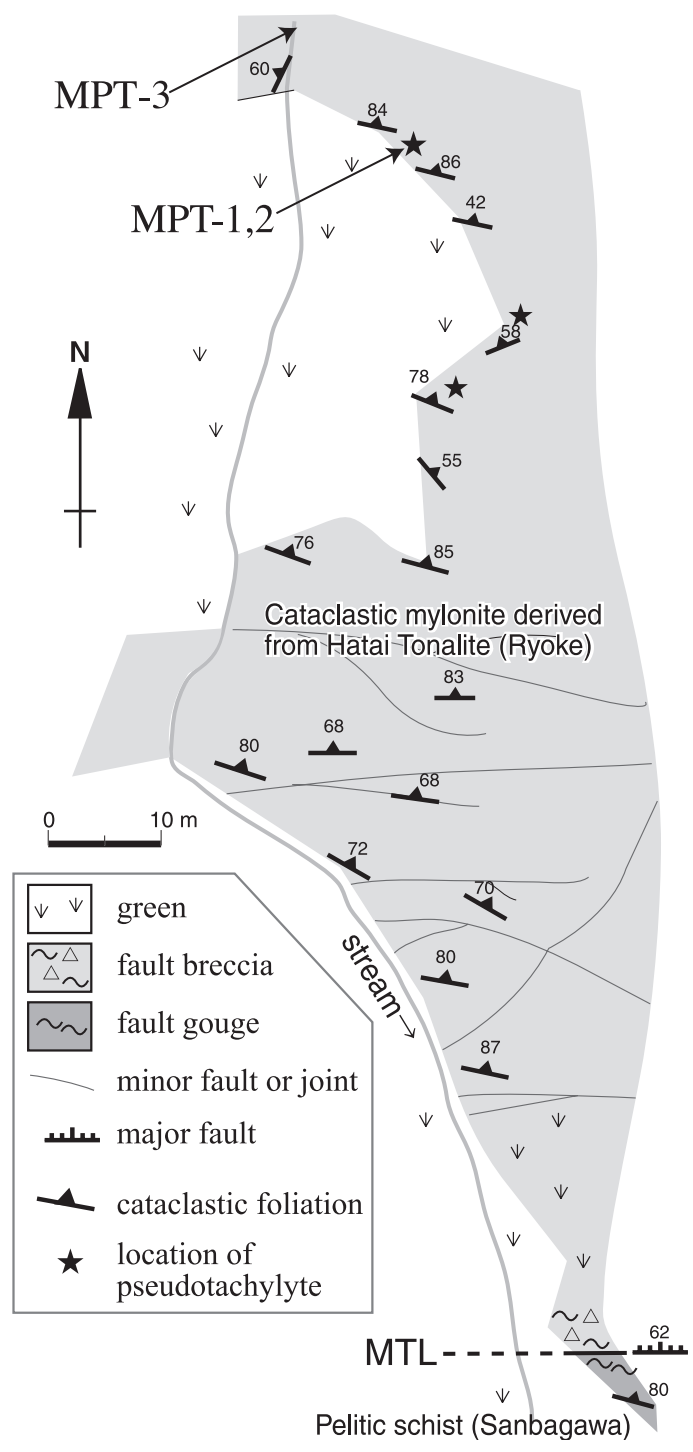

Fig. 2. Route map of the outcrop of the MTL including pseudotachylyte locations, Taki area, Mie Prefecture, southwest Japan. 

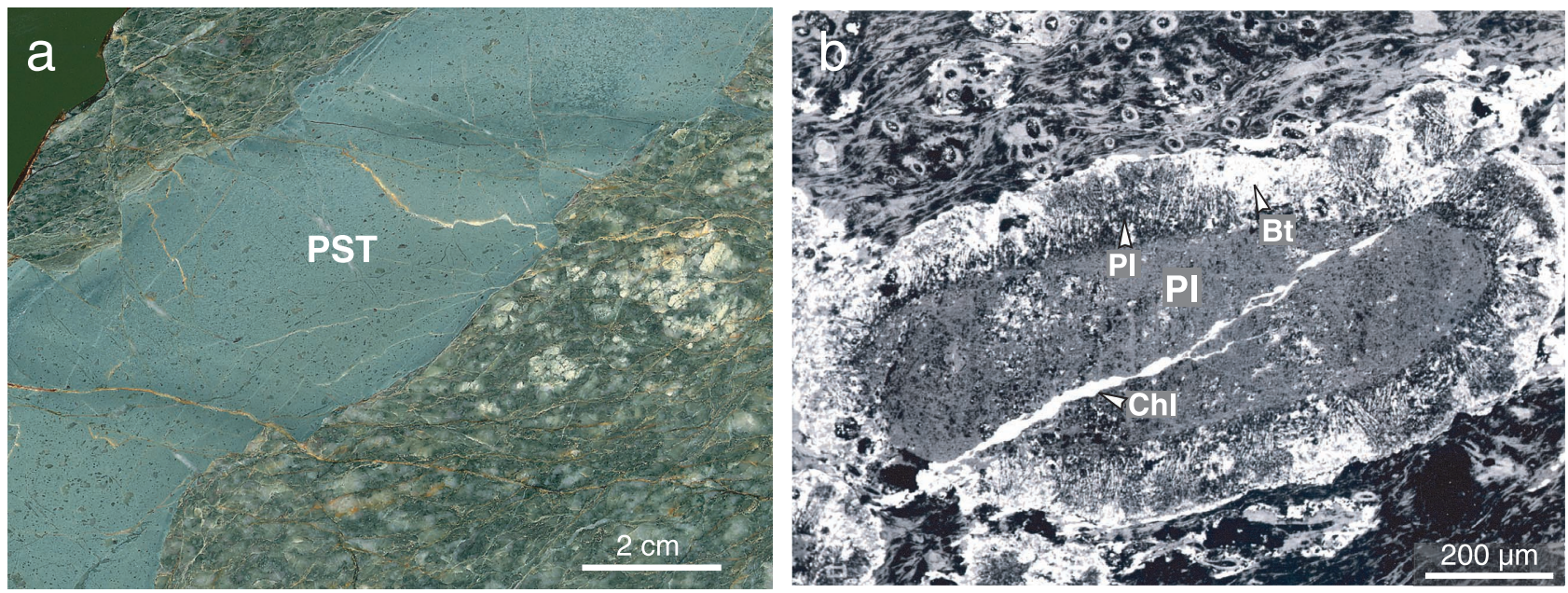

Fig. 3. Microstructures in the analyzed pseudotachylyte sample (MPT-1). (a) Photograph of polished slice of dated pseudotachylyte (PST) that was injected into the protolith mylonite. (b) Photomicrograph (backscattered electron image) of altered plagioclase fragment with decomposed mantle consisting of spherulitic microlites of plagioclase and biotite. Pl: plagioclase, Bt: biotite, Chl: chlorite vein.

was not so highly fractured and preserve mylonitic microstructures.

\section{Sample analyzed}

The thickest PST vein $(\sim 7 \mathrm{~cm}$ thick $)$ has a greyish bluegreen colour and this was used for FT dating (sample MPT-1: Fig. 3.a). Typical melt-quench textures such as chilled margins, flow layering, microlites or spherulitic microlites and amygdales are ubiquitous in the PST (Shimada et al., 2001). Plagioclase fragments suffered decomposition at their margin and thus become rounded shape (Fig. 3.b). Protolith tonalites were also collected for FT dating from $10 \mathrm{~cm}$ (sample MPT-2) and $15 \mathrm{~m}$ (sample MPT-3) apart from the PST vein (Fig. 2) . Fine-grained quartz aggregates showing typical mylonitic microstructure in the protolith occur as subrounded fragments. Mineral veins composed of chlorite (Fig. 3.b), calcite, chlorite + calcite, and calcite + hematite cut the PST veins, indicating that the formation of these mineral veins, accompanied by cataclasis, postdates the PST formation

\section{FT dating}

Zircon and apatite crystals were separated using conventional heavy liquid and magnetic techniques. About 400 zircon grains were separated from $410 \mathrm{~g}$ of PST sample, most of which are fine-grained, rounded and dark brownish. The host rock samples contain about 1000 zircon grains per $100 \mathrm{~g}$ of raw sample. The zircon grains are coarse-grained, euhedral and in pale brown with transparency. For each sample, 100-150 zircon grains were mounted in a PFA (fluorocarbon resin that consists of tetrafluoroethylene-perfluoroalkoxyethylene) sheet and polished with 3 $\mu \mathrm{m}, 1 \mu \mathrm{m}$ and $0.25 \mu \mathrm{m}$ diamond pastes. They were then etched with $\mathrm{KOH}$ : $\mathrm{NaOH}$ eutectic melt at $225^{\circ} \mathrm{C}$ for $24 \mathrm{~h}$ to reveal spon- taneous tracks. For sample MPT-3 only, sufficient apatite grains were separated. About 50 apatite grains were mounted in an epoxy resin and polished by the same method as zircon. Spontaneous tracks were etched in $0.7 \% \mathrm{HNO}_{3}\left(20^{\circ} \mathrm{C}\right)$ for $4 \mathrm{~min}$. Zircon or apatite mounts were packed for irradiation including NIST-SRM612 standard glass dosimeters. Diallyl phthalate (DAP) plastic detectors (Yoshioka et al., 2003) were used for inducedtrack counts of zircon, apatite and the glass dosimeter. These samples were irradiated in a pneumatic tube of the JRR- 4 or the JRR-3 reactor at the Japan Atomic Energy Agency (JAEA). The FT ages were determined using the external detector method (ED1: Danhara et al., 1991, 2003) and calibrated by the zeta calibration approach (Hurford and Green, 1983). Personal zeta factors have been published in Danhara et al. (2007) and Danhara and Iwano (2009). Only grains having sharply etched scratches and well-etched tracks in all directions were selected. Additionally, data were examined to determine if the grains belong to a single population using the $\chi^{2}$ test with statistical significance of $5 \%$ (Galbraith, 1981). Also was confined track length measurement carried out in order to evaluate thermal history of the dated samples.

The results of the FT dating and FT length measurement are shown in Table 1. The histograms of confined FT length distribution are shown in Fig. 4. For zircon, the FT dating of MPT-1 PST domain yields the age of $60.0 \pm 3.5 \mathrm{Ma}$, whereas the FT dating of protolith samples yields the ages of $70.2 \pm 2.7 \mathrm{Ma}$ (MPT-2), $72.1 \pm 2.1 \mathrm{Ma}$ and $67.7 \pm 1.9 \mathrm{Ma}$ (MPT-3). Mean confined FT lengths were obtained to be $10.7 \pm 0.1 \mu \mathrm{m}$ for the PST and $10.8 \pm 0.1 \mu \mathrm{m}$ for both host rocks. For apatite from MPT-3, a FT age was determined to be $38.0 \pm 1.5 \mathrm{Ma}$, and a mean confined FT length was measured to be $14.1 \pm 0.2 \mu \mathrm{m}$. 
Table 1. Zircon and apatite fission-track analytical data of the MTL pseudotachylyte and the protolith tonalites.

\begin{tabular}{|c|c|c|c|c|c|c|c|c|c|c|}
\hline Sample name & Mineral & $\begin{array}{l}\text { No. of } \\
\text { grains }\end{array}$ & $\begin{array}{c}\text { Spontaneous } \\
\rho_{\mathrm{s}}\left(\mathrm{cm}^{-2}\right) \\
\left(\mathrm{N}_{\mathrm{s}}\right)\end{array}$ & $\begin{array}{c}\text { Induced } \\
\rho_{\mathrm{i}}\left(\mathrm{cm}^{-2}\right) \\
\left(\mathrm{N}_{\mathrm{i}}\right)\end{array}$ & $\begin{array}{c}\text { Dosimeter } \\
\rho_{\mathrm{d}}\left(\mathrm{cm}^{-2}\right) \\
\left(\mathrm{N}_{\mathrm{d}}\right)\end{array}$ & $\begin{array}{l}\mathrm{P}\left(\chi^{2}\right) \\
(\%)\end{array}$ & $r$ & $\begin{array}{c}\mathrm{U} \\
(\mathrm{ppm})\end{array}$ & $\begin{array}{c}\text { Age }( \pm 1 \sigma) \\
(\mathrm{Ma})\end{array}$ & $\begin{array}{c}\text { Confined-track length } \\
\text { mean } \pm 1 \sigma \text { (number) } \\
\text { [range] }(\mu \mathrm{m})\end{array}$ \\
\hline MPT-1 (PST) & zircon & 27 & $\begin{array}{c}8.07 \times 10^{6} \\
(1694) \\
\end{array}$ & $\begin{array}{c}1.88 \times 10^{6} \\
(394) \\
\end{array}$ & $\begin{array}{c}7.280 \times 10^{4} \\
(4368) \\
\end{array}$ & 94 & 0.578 & 240 & $60.0 \pm 3.5$ & $\begin{array}{c}10.7 \pm 0.1(30) \\
{[9.65-12.15]}\end{array}$ \\
\hline $\begin{array}{l}\text { MPT-2 (protolith) } \\
\mathrm{D}=10 \mathrm{~cm}\end{array}$ & zircon & 30 & $\begin{array}{c}8.31 \times 10^{6} \\
(5110)\end{array}$ & $\begin{array}{c}1.65 \times 10^{6} \\
(1015)\end{array}$ & $\begin{array}{c}7.279 \times 10^{4} \\
(4367)\end{array}$ & 62 & 0.676 & 210 & $70.2 \pm 2.7$ & $\begin{array}{c}10.8 \pm 0.1(33) \\
{[9.66-12.31]}\end{array}$ \\
\hline $\begin{array}{l}\text { MPT-3 (protolith) } \\
\mathrm{D}=15 \mathrm{~m}\end{array}$ & zircon & 30 & $\begin{array}{c}8.17 \times 10^{6} \\
(6255)\end{array}$ & $\begin{array}{c}3.48 \times 10^{6} \\
(2665)\end{array}$ & $\begin{array}{c}1.492 \times 10^{5} \\
(4475)\end{array}$ & 66 & 0.883 & 220 & $72.1 \pm 2.1$ & $\begin{array}{l}10.8 \pm 0.1(35) \\
{[9.65-12.38]}\end{array}$ \\
\hline & zircon & 30 & $\begin{array}{c}7.68 \times 10^{6} \\
(6839)\end{array}$ & $\begin{array}{c}3.00 \times 10^{6} \\
(2666)\end{array}$ & $\begin{array}{c}1.282 \times 10^{5} \\
(4614)\end{array}$ & 39 & 0.774 & 220 & $67.7 \pm 1.9$ & \\
\hline & apatite & 30 & $\begin{array}{c}1.26 \times 10^{6} \\
(1068)\end{array}$ & $\begin{array}{c}5.64 \times 10^{6} \\
(4769)\end{array}$ & $\begin{array}{c}1.011 \times 10^{6} \\
(4854)\end{array}$ & 46 & 0.740 & 60 & $38.0 \pm 1.5$ & $\begin{array}{l}14.1 \pm 0.2(15) \\
{[13.10-15.82]}\end{array}$ \\
\hline
\end{tabular}

$\rho$ and $N$, density and total number of counted tracks, respectively; Analyses were made by the external detector method that applies to internal surfaces (ED1: Danhara et al, 1991); A NIST-SRM612 standard glass was used as a dosimeter; $\mathrm{P}\left(\chi^{2}\right)$, probability of obtaining the $\chi^{2}$ value for $v$ degrees of freedom ( $v=$ number of crystals - 1) (Galbraith, 1981); r, correlation coefficient between $\rho_{\mathrm{s}}$ and $\rho_{\mathrm{i}} ; \mathrm{U}$, uranium content calculated from the induced track densities (Iwano et al., 2000); Zircon and apatite grains were irradiated using the pneumatic tube of JRR-4 or JRR-3 reactors at the Japan Atomic Energy Agency, Japan; Ages were calculated by using zeta calibration factors of $\zeta_{\text {zircon }}=385 \pm 4(1 \sigma)$ for JRR-4 reactor, and $\zeta_{\text {zircon }}=414 \pm 3(1 \sigma)$ and $\zeta_{\text {apatite }}=337 \pm 4(1 \sigma)$ for JRR-3 reactor; D, Distance from the pseudotachylyte (MPT-1) vein wall; All track counts and track length measurements were done by HI; A weighted average of three zircon ages for protolith samples (MPT-2 and MPT-3) is calculated to be $69.8 \pm 1.2(1 \sigma)$ by the method of Taylor (1982).

\section{Discussion}

Based on the mean confined FT length $(10.8 \mu \mathrm{m})$ and its unimodal distribution for the both protolith tonalities, zircon FT ages of them are not affected by heat from the PST vein. For example, the FT length analyses across a thick $(11 \mathrm{~cm})$ pseudotachylyte from the Asuke Shear Zone (Murakami et al., 2006a) revealed that the partially annealed zone is less than $2 \mathrm{~cm}$ far from the vein margin. In this study, the average thickness of the PST is about $5 \mathrm{~cm}$ and thus the partially annealed zone must have been thinner $(\mathrm{c} .<1 \mathrm{~cm})$ than that of the Asuke Shear Zone if the melting temperature of both PST is similar. We consider, therefore, the FT age (70.2 Ma) for protolith $10 \mathrm{~cm}$ from the PST vein margin is a cooling age of protolith granite as well as the case of the protolith $15 \mathrm{~m}$ from the PST. We can calculate a weighted average (Taylor, 1982) of three zircon FT ages for the protolith samples to be $69.8 \pm 1.2 \mathrm{Ma}$. This host rock age is considered to be distinct from the age of the PST $(60.0 \pm 3.5 \mathrm{Ma})$ with $2 \sigma$ significance level. Therefore, we lead a conclusion that the PST was formed at about $60 \mathrm{Ma}$. This is supported by the mean confined FT length $(10.7 \mu \mathrm{m})$ with unimodal distribution in the PST sample (Fig. 4) indicating that fission tracks in zircon were completely annealed during the PST formation, which is also suggested by the decomposition of feldspar fragment in the fairly thick PST vein $(5 \mathrm{~cm})$, and that the sample was quenched and then has not been affected by secondary heating.

Because zircon and apatite FT ages of the host rock (protolith) were $70 \mathrm{Ma}$ and $38 \mathrm{Ma}$, respectively, the PST was formed during cooling down of the Ryoke granite at temperatures between the closure temperature of zircon FT system (about $250{ }^{\circ} \mathrm{C}$ : Hurford, 1986; Tagami et al., 1995) and that of apatite $\left(100{ }^{\circ} \mathrm{C}\right.$ : Wagner and Van den haute, 1992). The facts that the PST was formed after major cataclastic deformation along the MTL and that the PST was overprinted by cataclasis (Shimada et al., 2001) are consistent with the above temperature estimation.

The PST age is comparable to the oldest group of $\mathrm{K}-\mathrm{Ar}$ ages for fine grain fraction $(<2 \mu \mathrm{m})$ including mica clay minerals of the MTL fault gouges derived from both Sanbagawa pelitic schist and Izumi Group (Ryoke) in Shikoku (58-62 Ma: Shibata et al., 1989). In these $\mathrm{K}-\mathrm{Ar}$ ages, the date (60.1 Ma) from the MTL fault gouge derived from the Sanbagawa pelitic schist at Hiruma, Tokushima Prefecture, is considered to be the most reliable result, because the illite crystallinity index clearly indicates that it is the product of hydrothermal alteration associated with major fault activity and not pulverized muscovite derived from the schist protolith. The $\mathrm{K}-\mathrm{Ar}$ and $\mathrm{FT}$ ages of about $60 \mathrm{Ma}$ represent the oldest record of brittle deformation along the MTL. We propose that this age also shows that juxtaposition of the Sanbagawa rocks against the Ryoke rocks at a shallow crustal depth had already started by 60 Ma. This stage of the MTL activities was probably top-to-the-north normal faulting associated with the early stage of exhumation of the Sanbagawa schist referring to the recent contributions of the structural analyses along the MTL by Fukunari and Wallis (2007), Kubota and Takeshita (2008), and El-Fakharani and Takeshita (2008). This age is also similar to the zircon FT ages of PST in the Ryoke granitic rocks from the Nojima Fault (56 Ma: Murakami and Tagami, 2004) and from the Asuke Shear Zone (53 Ma: Murakami et al., 2006a). 

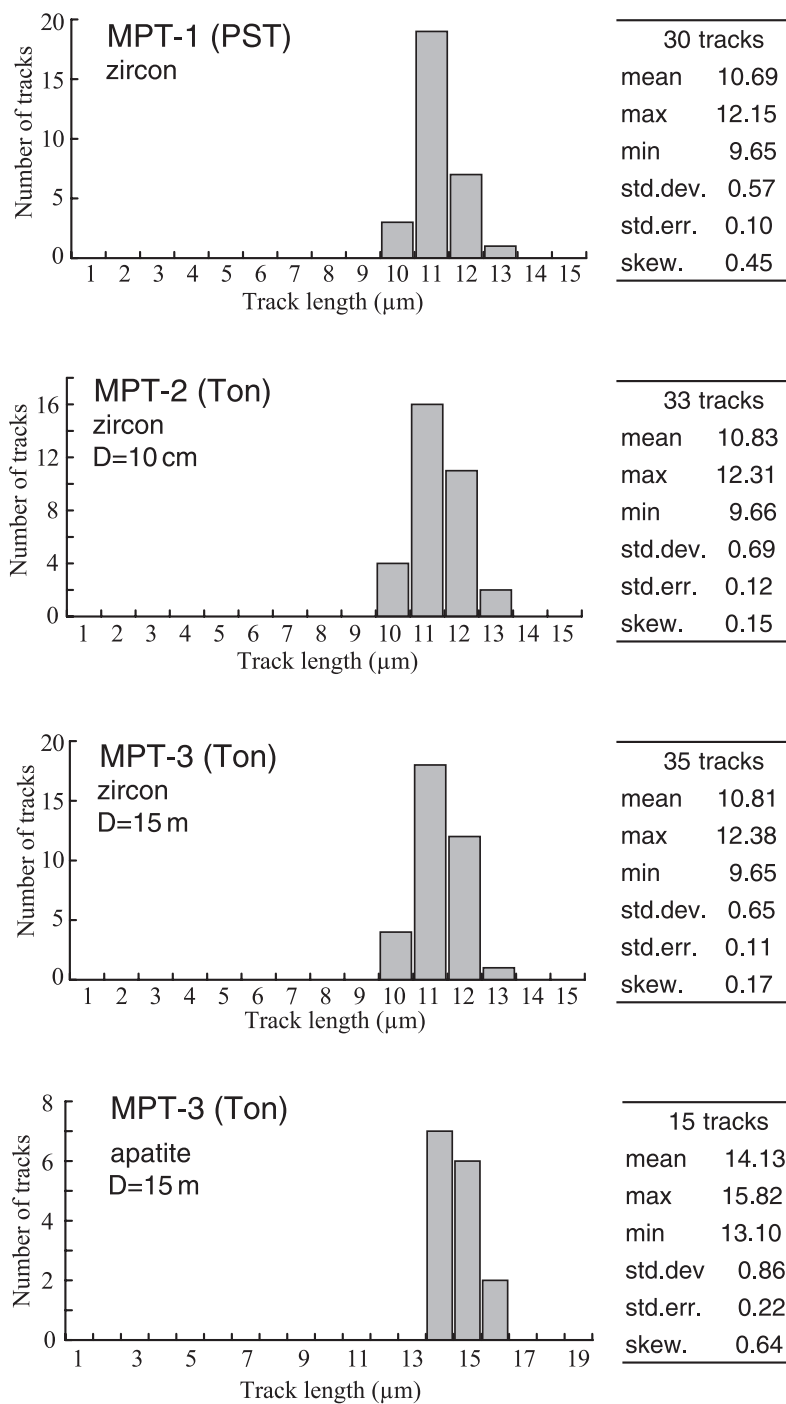

\begin{tabular}{lr}
\hline \multicolumn{2}{c}{15 tracks } \\
mean & 14.13 \\
max & 15.82 \\
min & 13.10 \\
std.dev & 0.86 \\
std.err. & 0.22 \\
skew. & 0.64 \\
\hline
\end{tabular}

Fig. 4. Confined fission track-length distribution in zircon grains in pseudotachylyte (MPT-1) and in zircon and apatite grains in protolith mylonitized tonalite (MPT-2, 3). D: distance from the PST vein margin (MPT-1).

These PST ages are younger than the protolith FT ages (73-74 Ma: Murakami and Tagami, 2004; Murakami et al., 2006a), therefore the formation of these major faults in the Ryoke Belt was started at about 60-50Ma during the cooling stage of the Ryoke granitic rocks in brittle regime below the closure temperature (c. $250{ }^{\circ} \mathrm{C}$ ) of zircon

\section{Acknowledgements}

We thank Dr. Simon Wallis and an anonymous reviewer, and Dr. Toru Takeshita (editor) for their constructive comments, which helped us to improve this manuscript. This research was supported from the JSPS Grant-in-aid for Scientific Research (20540449) to H. Takagi.

\section{References}

Danhara, T. and Iwano, H., 2009, Determination of zeta values for fissiontrack age calibration using thermal neutron irradiation at the JRR-3 reactor of JAEA, Japan. Jour. Geol. Soc. Japan, 115, 141-145.

Danhara, T., Iwano, H., Kobayashi, H. and Tsuruta, T., 2007, A report on fission-track data of zircon and apatite age-standards for age calibration using diallyl phthalate (DAP) resin detectors and a minor revision of zeta values by Danhara et al. (2003). Jour. Geol. Soc. Japan, 113, $77-81$.

Danhara, T., Iwano, H., Yoshioka, T. and Tsuruta, T., 2003. Zeta calibration values for fission-track dating with a diallyl phthalate detector. Jour. Geol. Soc. Japan, 109, 665-668.

Danhara, T., Kasuya, M., Iwano, H. and Yamashita, T., 1991. Fission-track age calibration using internal and external surfaces of zircon. Jour. Geol. Soc. Japan, 97, 977-985.

El-Fakharani, A. -H. and Takeshita, T., 2008, Brittle normal faulting in the highest-grade Sambagawa metamorphic rocks of central Shikoku, southwest Japan: Indication of the exhumation into the upper crustal level. Jour. Asian Earth Sci., 33, 303-322.

Fukunari, T. and Wallis, S. R., 2007, Structural evidence for large-scale top-to-the-north normal displacement along the Median Tectonic Line in southwest Japan. Island Arc, 16, 243-261.

Galbraith, R. F., 1981, On statistical models for fission-track counts. Jour. Math. Geol., 13, 471-478.

Hurford, A. J., 1986, Cooling and uplift patterns in the Lepontine Alps South Central Switzerland and an age of vertical movement on the Insbric fault line. Contrib. Mineral. Petrol., 92, 413-427.

Hurford, A. J. and Green, P. F., 1983, The zeta age calibration of fissiontrack dating. Isotope Geoscience, 1, 285-317.

Iwano, H., Yoshioka, T. and Danhara, T., 2000, A review on fission-track equations for age and uranium content determinations: Towards the next-generation dating system. Fission Track News Lett., no. 13, 110 .

Kubota, Y. and Takeshita, T., 2008, Paleocene large-scale normal faulting along the Median Tectonic Line, western Shikoku, Japan. Island Arc, 17, 129-151.

Murakami, M., Košler, J., Takagi, H. and Tagami, T., 2006a, Dating pseudotachylyte of the Asuke Shear Zone using zircon fission-track and U-Pb methods. Tectonophysics, 424, 99-107.

Murakami, M. and Tagami, T., 2004, Dating pseudotachylyte of the Nojima fault using the zircon fission-track method. Geophys. Res. Lett. 31, L12604. doi: 10.1029/2004GL020211.

Murakami, M., Yamada, R. and Tagami, T., 2006b, Short-term annealing characteristics of spontaneous fission tracks in zircon: a qualitative description. Chem. Geol., Isot. Geosci. Sect., 227, 214- 222

Sakakibara, N., 1995, Structural evolution of multiple ductile shear zone system in the Ryoke belt, Kinki Province. Jour. Sci. Hiroshima Univ., Ser. C, 10,267-332.

Shibata, K., Nakajima, T., Sangawa, A., Uchiumi, S. and Aoyama, H., 1989, $\mathrm{K}$-Ar ages of fault gouges from the Median Tectonic Line in Shikoku. Bull. Geol. Surv. Japan, 40,661-671*.

Shimada, K., Kobari, Y., Okamoto, T., Takagi, H. and Saka, Y., 2001, Pseudotachylyte veins associated with granitic cataclasite along the Median Tectonic Line, eastern Kii Peninsula, Southwest Japan. Jour. Geol. Soc. Japan., 107, 117-128.

Shimada, K., Takagi, H. and Osawa, H., 1998, Geotectonic evolution in transpressional regime: time and space relationships between mylonitization and folding in the southern Ryoke belt, eastern Kii Peninsula, southwest Japan. Jour. Geol. Soc. Japan, 104, 825-844*.

Spray, J. G., 1992, A physical basis for the frictional melting of some rockforming minerals. Tectonophysics, 204, 205-221.

Tagami, T., Hasebe, N. and Shimada, C., 1995, Episodic exhumation of accretionary complexes: Fission-track thermochronologic evidence from the Shimanto Belt and its vicinities, southwest Japan. Island Arc, 4, 209-230.

Tagami, T., Lal, N., Sorkhabi, R. B., Nishimura, S., 1988, Fission track thermochronologic analysis of the Ryoke Belt and the Median Tec- 
tonic Line, southwest Japan. Jour. Geophys. Res., 93, 13705-13715.

Takagi, H., 1985, Mylonitic rocks of the Ryoke belt in the Kayumi area eastern part of the Kii Peninsula. Jour. Geol. Soc. Japan, 91, 637$651^{*}$.

Takagi, H., Arita, K., Danhara, T., Iwano, H., 2007, Timing of the Tsergo Ri Landslide, Langtang Himal, determined by fission-track age for pseudotachylyte. Jour. Asian Earth Sci, 29, 466-472.

Takagi, H., Shibata, K., Sugiyama, Y., Uchiumi, S. and Matsumoto, A., 1989, Isotopic ages of rocks along the Median Tectonic Line in the Kayumi area, Mie Prefecture. Jour. Mineral. Petrol. Econ. Geol., 84, 75-88*.

Takagi, H., Shimada, K., Saka, Y., Arai, S., Kobari, Y. and Okamoto, T., 2001, Pseudotachylytes in the Ryoke Belt. Jour. Geol. Soc. Japan, 107, Pictorial III-IV ${ }^{* *}$.

Taylor, J. R., 1982, An Introduction to Error Analysis: The Study of Uncertainties in Physical Measurements 2nd ed. Univ. Sci. Books, Sausalito, California, 327p.

Wagner, G. A. and Van den haute, P., 1992, Fission-Track Dating. Kluwer Acadmic Publisher, Dordrecht, 285p

Yoshioka, T., Tsuruta, T., Iwano, H., Danhara, T. and Koguchi, Y., 2003 Fission-fragment registration and etching properties of diallyl phtha-

late with reference to its use as an external detector in fission track dating. Nucl. Instr. Meth. Phys. Res. B, 207, 323-332.

* in Japanese with English abstract

** in Japanese

\section{用語対比}

Asuke Shear Zone

Hatai tonalite

Hiruma

Izumi Group

Kuzukayama

Nojima Fault

Ryoke granitic rocks

Sanbagawa peltic schist

Taki
足助剪断帯

畑井トーナル岩

昼間

和泉層群

国束山

野島断層

領家花崗岩類

三波川泥質片岩

多気

\section{（要 旨）}

Takagi, H., Shimada, K., Iwano, H. and Danhara, T., 2010, Oldest record of brittle deformation along the Median Tectonic Line: fission-track age for pseudotachylyte in the Taki area, Mie Prefecture. Jour. Geol. Soc. Japan, 116, 45-50（高木秀雄・島田耕史・岩野英 樹・檀原 徹, 2010, 中央構造線の脆性変形の最古の記録 : 三重県多気地域のシュード夕 キライトのフィッショントラック年代. 地質雑, 116, 45-50).

三重県多気町の中央構造線（MTL）に伴われるシュードタキライト（PST）のフィッショ ントラック（FT）年代を報告し，MTL の活動史を議論した。 PST 脈のジルコン FT 年代は $60.0 \pm 3.5 \mathrm{Ma}$ であった。一方，PST から $10 \mathrm{~cm}$ および $15 \mathrm{~m}$ はなれた畑井トーナル岩由来 のマイロナイトは，3 試料の重み付き平均值として $69.8 \pm 1.2 \mathrm{Ma}$ という PSTよりも有意 に古い值が得られた。PST に観察される長石の分解組織はジルコン内の既存のトラックを 瞬間に消滅させるに充分な温度に達したことを示唆し, PST のトラック長解析はその FT 年代が摩擦熱融解時に完全にアニールされたことを示す。一方，母岩の燐灰石の FT 年代 が $38.0 \pm 1.5 \mathrm{Ma}$ であることから，母岩の冷却時の $250 \sim 100{ }^{\circ} \mathrm{C}$ 条件で PST が生成した ことが明らかとなった。今回の約 $60 \mathrm{Ma}$ という年代は，MTLの断層ガウジの最古の年代と 一致する. 